\title{
Treatment of humerus nonunion using G.A. Ilizarov Technique
}

\begin{abstract}
The management of the humerus nonunion is one of the most challenging problems that the surgeon confronts in his practice. The procedures traditionally used are: I.M. Nailing, interlocking, plating, transplantation of allograft. In our series, 56 cases with nonunion has been treated by G.A. Ilizarov technique. The age range was: 21-62 years with an average of 32 years. The initial treatment was done by DCP, rush nails \& plates with screw fixation. The duration of treatment ranged from 5-11 months (average 8 months). With the Ilizarov fixator application a good range of elbow \& shoulder motion were achieved. The average follow up period was 15 years with a range of 1-22 years. Union was achieved in all the 56 cases.
\end{abstract}

Keywords: Humerus Non Union, Ilizarov Technique
Volume 2 Issue 2 - 2015

\author{
Bari MM, Shahidul Islam, Shetu NH, Mahfuzer \\ RM, Ferdousi N \\ Bari-llizarov Orthopaedic Centre, Bangladesh
}

Correspondence: Mofakhkharul Bari, Bari-llizarov

Orthopaedic Centre, 72, Satmasjid Road, Nizams Shankar Plaza, Dhanmondi, Dhaka, Bangladesh, Tel 8801819211595,

Email bari.ilizarov31@gmail.com

Received: February II, 2015 | Published: March 18, 2015

\section{Introduction}

Humeral non unions are often painful and unstable Good surgical management is sometimes very difficult. Fixation with plates and screws and bone grafting may fail. The outcome of revision operation may be adversely affected by restricted movement of elbow. In most cases, the patient has been several times operated with resultant scarring and cicatrisation of the surrounding soft tissues. This renders the environment around the fracture site avascular. Nonunion occurs most commonly in transverse or comminuted middle and lower one third fractures, fractures with distraction or soft tissue interposition, open injuries, infection and fractures treated by internal fixation. Nonunion rate in closed fractures varies from $0-6 \%$, while the nonunion rate after open reduction ranges from $0-12 \% .{ }^{1}$ Success rates after DCP and autogenous grafting ranges from $90-95 \%$. Recent studies showed that the G.A. Ilizarov Technique is more popular than vascularized bone grafts for humeral shaft nonunions. ${ }^{1-5}$

\section{Results}

In all the 56 patients' bony union were achieved. The mean period for bony union is 7 months, range 5-11 months (Table 1). The main aetiology was open fracture as presented in Table 2.

Table I Table Shows sex incidence and its percentage

\begin{tabular}{lll}
\hline Sex & Number & Percentage (\%) \\
\hline Female & 37 & $66.00 \%$ \\
Male & 19 & $34.00 \%$ \\
\hline
\end{tabular}

Table 2 Shows Aetiology

\begin{tabular}{ll}
\hline *open fractures & 31 cases \\
$*$ Complication of surgically treated & 17 cases \\
fractures (failed open reduction) & \\
$*$ Osteomyelitis & 08 cases \\
Total $=$ & 56 cases \\
\hline
\end{tabular}

\section{Discussion}

Nailing plating and bone grafting are the accepted traditional method of managing nonunion of humerus. But a significant number of patients requires other procedures. G.A. Ilizarov method for the treatment of humeral nonunion has many advantages. But several technical problems may arise if the details of the technique are not followed precisely. For successful outcome it is important to maintain the bone ends in good and stable fixation. In order to provide firm stability and to avoid axial deviation during distraction, the assembly of fixator in our cases usually required one or two rings proximally, one or two distally. Another important factor is to achieve good contract of the bones. A partial contact in one of our cases was the cause of nonunion; but in that case we re-fixed the apparatus and later on good union was achieved. Fixation with Ilizarov apparatus in the upper middle and lower third by using Schanz screw with 90o arch and oblique support is biomechanically and anatomically superior to that with a plate. ${ }^{1,3,5,6-10}$ The most important thing is that the patient can mobilize the shoulder and elbow soon after the operation with Ilizarov apparatus.

\section{Conclusion}

The Ilizarov technique for the treatment of humeral nonunion is very effective and offer many advantages. The advantages of this technique are that it allows for the simultaneous treatment of infection, nonunion, shortening, deformity and problems of soft tissues. In our all cases complications were not severe and did not influence the results (Figure 1-4).
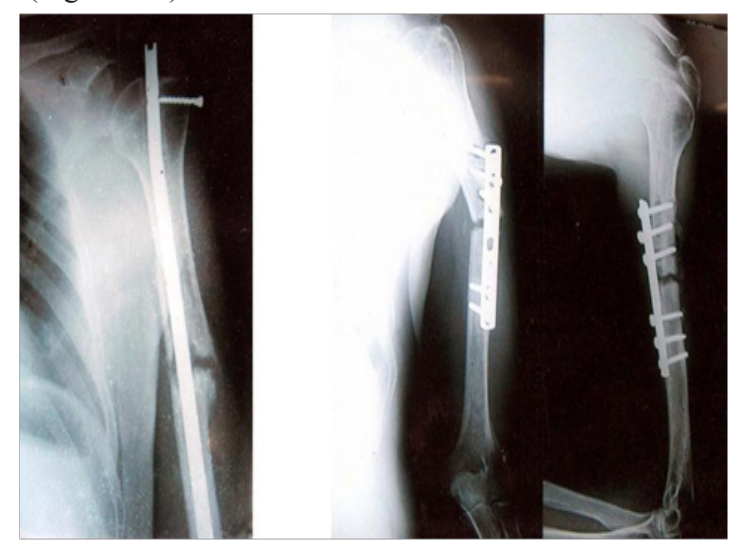

Figure I Radiographic view of nonunion left humerus with interlocking nail in situ and Radiographic view of the same patient, again plating was done; nonunion persists. 


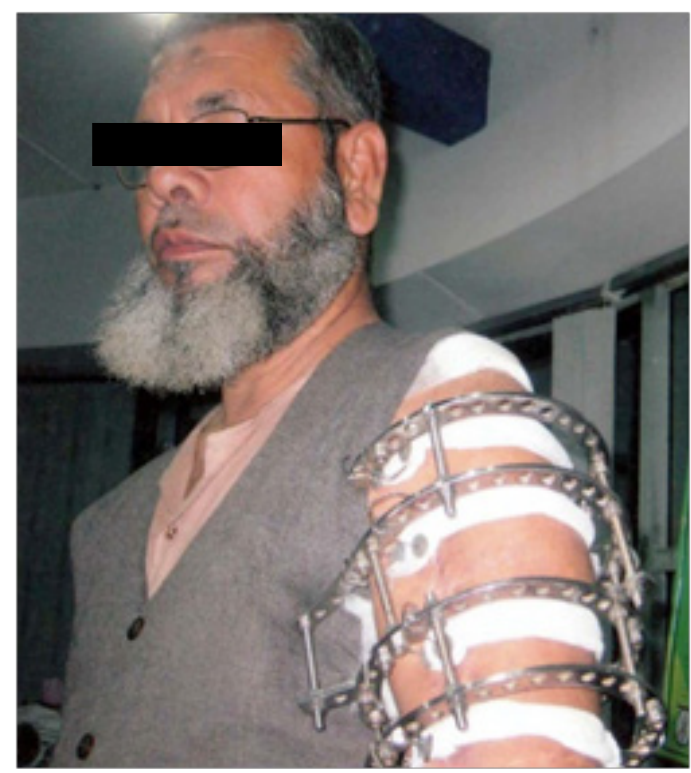

Figure 2 The same patient, plate and screws removed and llizarov ring fixator applied.

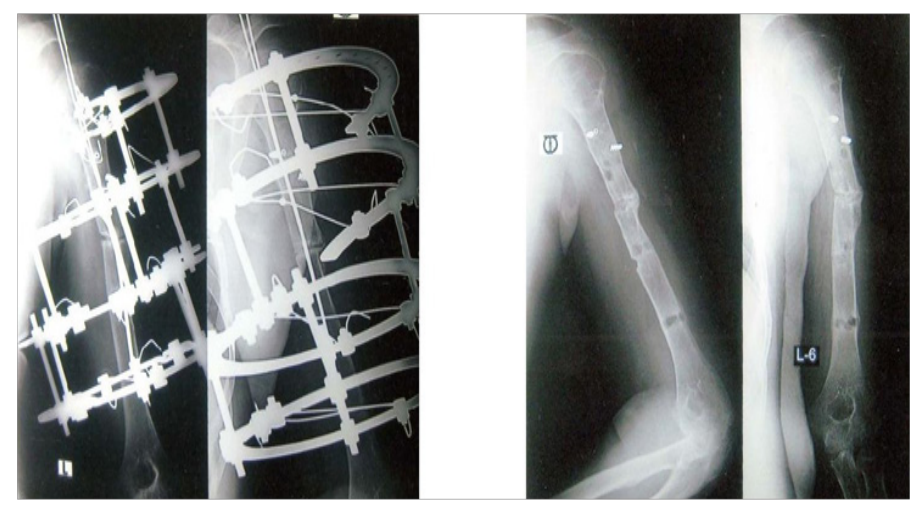

Figure 3 Radiographic view of left humerus with the llizarov fixator in situ and Radiographic view of left humerus, full union is achieved.

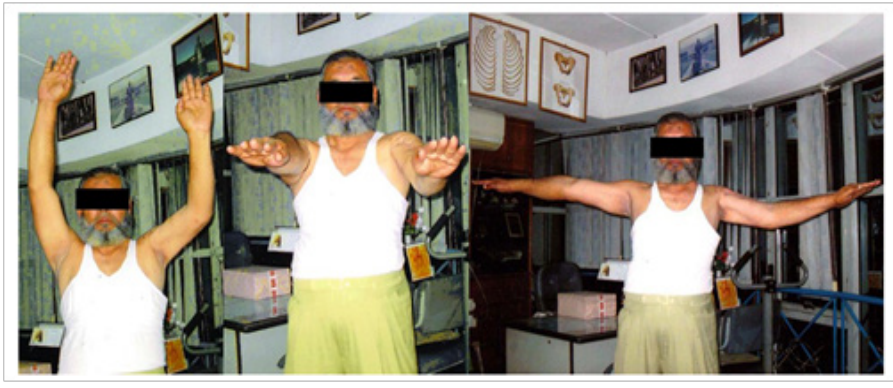

Figure 4 Final clinical photograph of the patient.

\section{References}

1. Bari MM. A color atlas of limb lengthening, surgical reconstruction and deformity correction by Ilizarov technique. 2013;pp. 336-339.

2. Charles H, Epps JR.With 60 contributions: Complications in Orthopaedic surgery, JB Lippincott company, NewYork, USA, 1978;pp. 215-235.

3. Paley D, Catagni MA, Argnani F, et al. Ilizarov treatment of nonunion with bone loss. Clin Orthop Relat Res. 1978;241:146-165.

4. Golyakhovasky V, Frankel V. Operative manual of Ilizarov techniques. Mosby, USA, 1993.

5. Ilizarov GA. The tension-stress effect on the genesis and growth of tissues 11: The influence of the rate of frequency of distraction. Clin Orthop Relat Res. 1990;239:263-285.

6. Catagni MA, Guerresci F, Probe RA. Treatment of humeral nonunion with the Ilizarov technique. Bulletin of the hospital for joint diseases Orthopaedic Institute. 1991;51(1):74-83.

7. Subhash Kakkad. Ilizarov's operative techniques, Basic concepts and advances. 2002;133-137.

8. Jupitar JB, Goodman LJ. The management of complex distal humerus nonunion in the elderly by triple plating. J Shoulder Elbow Surg. 1992;1(1):37-46.

9. Kalnberg BK. Compression-distraction apparatus and system of stability. Riga. 1981;87-117.

10. Ilizarov GA. Transosseous osteosysthesis: Theoretical and clinical aspects of the regeneration and growth of tissue. Springer. 1992;453-495. 